\title{
Developmental Trend of City Exhibition Tourism under the Backgrounds of Concept Tourism and Ecological Tourism
}

\author{
Ting Zhao
}

Qinghai University School of Finance and Economics, Xining City, Qinghai Province 810016, China.

Keywords: Exhibition Tourism, Developmental, Backgrounds, Concept, Ecological.

\begin{abstract}
In this manuscript, we analyze the developmental trend of city exhibition tourism under the backgrounds of concept tourism and ecological tourism. Along with the continuous expansion of the convention and exhibition industry, the tourism industry of basic convention and exhibition activities support role played more and more obvious, a batch of tourism enterprises begin to convention and exhibition business and achieved good economic benefits. Convention and exhibition activities and tourism can and must achieve effective docking has become the consensus of the convention and the exhibition industry and tourism industry. This paper proposes the new perspective of the related and relevant understandings and ideas that will be meaningful.
\end{abstract}

\section{Introduction}

Conference exhibition tourism is inevitable after industrialization, diversification of new way of the tourism activities. This kind of comprehensive travel service has a group scale, high grade, guest stay long, strong consumption ability and advantages of the profits. Conference and exhibition tourism development can improve visibility and reputation of a region or city, promote the improvement of the urban infrastructure, and promote exchanges and cooperation between regions. Compared with the conventional tourism, the conference exhibition tourism is stronger, and the correlation of higher economic benefits and social benefits. Overall, especially in the foreign countries of Germany, France and other advanced economies, meeting exhibition organizers in the industry management, facilities, convention and exhibition promotion and so on have been more mature, and basic tourism special relationship related conference exhibition organizers and running mechanism of theoretical research is also relatively more as domestic convention and exhibition tourism research is still in its infancy.

\begin{tabular}{|c|l|}
\hline ENVIRONMENT & $\begin{array}{l}\text { Reduction of } \mathrm{CO} 2 \text { emissions; Use of renewable energy } \\
\text { sources, monitoring on energy consumptions }\end{array}$ \\
\hline LIVING & $\begin{array}{l}\text { Co-working, Cultural initiatives, Living-Lab, } \\
\text { crowdsourcing co-design }\end{array}$ \\
\hline MOBLITY & $\begin{array}{l}\text { Development of technologies to improve urban mobility, } \\
\text { low envoronmental impact }\end{array}$ \\
\hline GOVERNANCE & $\begin{array}{l}\text { Starting of processes for the involvment of citizens about topics } \\
\text { of public rilevance }\end{array}$ \\
\hline ECONOMY & $\begin{array}{l}\text { Cooperation among public and private actors, } \\
\text { developmento of social incubators and of small and } \\
\text { medium enterprises }\end{array}$ \\
\hline PEOPLE & $\begin{array}{l}\text { Sharing of data, security and protection of sources, } \\
\text { networking and comunication }\end{array}$ \\
\hline
\end{tabular}

Fig. 1 The General Characteristics of the Modern Tourism Activities

That cause ecological tourism concept and connotation of generalization of the most fundamental reason lies in the definition of ecotourism is not properly for ecological tourism, ecological tourism to understand or confuse with ecological tourism and ecological tourism, this to some extent, and people often confuse in basic tourism activities and tourism two concepts together has obvious similarities. 
Although the development of ecological tourism activity has become the consensus of all mankind, but the development of ecological tourism is not plain sailing. From the foregoing problems shown in ecological tourism activities in our country, will be able to see it. Actually this kind of phenomenon in ecological tourism activities is good country as well. As used by human natural landscape methods and tools of continuous improvement, as intensity of human disturbance to the landscape is becoming more and more big, on the one hand, we live in the earth's ecosystem has not completely not subjected to human interference exists, but on the other hand, the influence of core human interference is not balanced, there are various human disturbance intensity on the earth's ecological system, therefore the earth all area is a certain natural properties, also with a certain characteristics of human influence.

Under this circumstance, in the later sections, we will discuss the developmental trend of the city exhibition tourism under the backgrounds of concept tourism and ecological tourism in detail.

\section{The Principles of Our Methodology}

Ecological Tourism. Civilization is the sum of the human creation of wealth it is an advanced state of social and cultural development and achieves this state of the process. It reflects the degree of general development of human society, the characterization of a country or basic nation economic, social and cultural development level and the overall appearance. From completely depend on the nature of the primitive civilization to respect nature of general agricultural civilization and industrial civilization to remake nature, to determining the nature of ecological civilization this is a spiral and inevitable trend in the development of human civilization [1-2].



Fig. 2 The Keywords of the Ecological Tourism Principles

Earlier than countries with eco-tourism, nature reserve in China was virtually zero on the threshold of ecological tourism and general nature reserves to develop ecological tourism is a lack of scientific management and supervision mechanism, and combined with some reserve that focus on the tourism economic benefits, ignore the protection of resources and management, environmental problems of caused by tourism are becoming more and more outstanding. For these challenges, we list solutions.

- Ecological tourism is a wide covering range, involves many factors, knowledge composition new and high technical content of the comprehensive system engineering, so we must be in the point of view of system problems, based on the latest scientific theory.

- The essential characteristics of ecotourism decided it must have been a persistent activity, combined with China's vast, circumstances vary in different parts of nature, and the imbalance of the regional economic development, etc., these require us to complete the basic work, but also in the development of ecological tourism activity when a conscientious attitude.

- According to principle of core management pattern in our country, on the one hand, should strengthen the function of the tourism administrative departments at all levels to the unified coordination, giving its corresponding power and responsibility, make the macro management of ecotourism development in the direction of the uniform, stable and orderly. 
Concept Tourism. Tourism products, tourism supply and tourism is the several basic concepts of economics, also is the logical starting point of the whole economics of the tourism research and so to speak, on the basis of the understanding of the concept and definition, directly affect the economics of tourism of the whole research system. In many parts of the whole country will tourism as the pillar industry and leading industry, one thousand ways to develop tourism, tourism supply exponentially, tourism appeared the remarkable feature of buyer's market, the status of tourism industry get a huge ascension and the market competition is very fierce [3].

The current domestic research on tourism supply chain is still in its initial stage as understanding of tourism supply chain mostly from the perspective of basic tourism product supply chain, the tourism industry supply chain. On the planning concept, the current domestic planning sector has yet to its special strict definition and explanation. Tourism concept planning is also called "conceptual tourism planning" or "conceptual tourism development planning" will be the concept planning of basic urban planning is applied to tourism planning, for the outline to tourism destination or scenic spots as the guidance of the general. The characteristics of the tourism concept planning can be listed as follows.

- Tourism concept planning of tourism destination overall and long-term development strategy, its most important value is also put forward a clear tourism strategic concept, therefore, the content must be guiding, summary and guidance, mainly related to the long-term development goals, tourism destination function orientation and development strategy.

- As a strategic planning method, thick line, the flexibility of tourism concept planning is not only simple in process planning technology, planning personnel less, on the amount of work.

- With the rapid development of economy and the speeding up of core economic globalization, tourism destination even a small tourist scenic areas, attractions will no longer be isolated closed geographical unit, but in the area of loop circle of international communication.

- In the era of knowledge economy, the innovation is the tourism industry to obtain the eternal theme of vitality. For tourism concept planning, its focal point, that is, the main concepts and ideas of tourism planning as is in the right under the market orientation of study design have market competitiveness of tourism products.

Conceptual tourism planning is only the product of the primary stage of tourism planning, rather than a new planning category that as a new planning concept or method. Thus it less affected by the inherent established mind-set, very conducive to emancipate the mind and make the plan itself more imagination and creative thinking, thus has vitality as need to get the preliminary planning of tourist destination. New tourism development or a very low level of the development of the general tourism development, due to not able to make a detailed survey or that only some perceptual knowledge, the development data is incomplete, unclear understanding of the relationship between tourism that can prepare the conceptual tourism planning as a preliminary planning scheme.

Exhibition Economy. The development of exhibition industry must rely on the basis of the city, especially the city's industrial base, geographical location, service base, only on the premise of fully considering their own conditions, to properly and timely in the process of the general city's economic development to promote the development of exhibition industry. In fact, the exhibition industry and the other industries that have its own rules and constraints, have some hard requirements on site.

According to the review, the forms of the exhibition economy can be organized as follows. (1) The exhibition economy is based on convention and exhibition industry through holding various forms of exhibition, exposition, and special conference, that form information flow, cash flow, logistics, flow, create business opportunities, stimulating the development of related industry a kind of economy. (2) Exhibition economy is based on convention and exhibition industry, through holding various forms of exhibition, exhibition and international meeting, convey information, provide service and create business opportunities, and use the knock-on effect to drive related industry. (3) Exhibition economy is accompanied by exhibition economy activities, convention and exhibition industry development to a certain historical stage formed across the industry, cross-regional comprehensive economic form. In particular that is held by all kinds of meetings, merchandise display and exhibition activities such as 
direct economic benefits have been obtained at the same time, drive a region or a city the development of relevant industries, achieve the purpose of promoting economic and social all-round development.

City Exhibition Tourism. Convention and exhibition tourism is an important part of basic urban tourism, while the role of government in the early stage of convention and exhibition tourism is very important, but the convention and exhibition tourism is a kind of economic behavior, its development should follow the market rules. At present our country that most of the convention and exhibition is needed by the local finance behind "pay" and the government to participate in the core exhibition are generally belongs to the comprehensive, such as investment and trade fair will, economic and trade fair, fair, and so on, but now some such as auto show, gifts, electronics and the other professional exhibition, the government has a large number of intervention [4-5].

This phenomenon is more or less will make our tourism market of their own development orbital, aggravate the burden of the government. Although the convention and exhibition tourism in the social and economic effects of special significant, but the meeting exhibition organizers itself not to carry on the marketing operation, as this to some extent, limits the convention and exhibition enterprise in the activities of large conference and the exhibition tourism should have the enthusiasm. Current industry association management system restricts the development of mice tourism industry association, the association need government approval to policy with the association of self-discipline, could become a tool of the core government. So in addition to set up exhibition management agencies and industry associations, as play the role, industry associations to coordinate the relation between the government and industry associations in the industry management, by planning the guidance and combining the industrial policy to promote the development of the society. Mice tourism industry association should also have organization coordinated and outreach and exemplary role, coordination of core exhibition institutions in the communication and cooperation with the hotel and other related enterprises in the problems and contradictions, to strengthen the cooperation with these companies, and reference and learning the foreign advanced experience for reference for domestic enterprises.

\section{Summary}

In this paper, we analyze the developmental trend of city exhibition tourism under the backgrounds of concept tourism and ecological tourism. Any tourist behavior is the ecological environment brings certain influence to the destination, even if the tourists don't offer to interfere with the ecological system of tourist sites, its tourist behavior still can bring certain influence on the ecological system. Only when the disturbance of this tourism activity intensity big, however, the natural ecosystem could resume in a very short period of time, can only be called ecotourism. Under this basis, we propose the city exhibition tourism paradigm with references to the concept tourism and ecological tourism that will modify and optimize the contemporary pattern of tourism in China.

\section{References}

[1] Wu, Rong, and Mu Zhang. "Research on the tourism effect and marketing strategy of convention \& exposition industry: A case study of Shenzhen City of China." Journal of Service Science and Management 6.2 (2013): 151.

[2] Whitfield, Julie, et al. "Attracting convention and exhibition attendance to complex MICE venues: Emerging data from Macao." International Journal of Tourism Research 16.2 (2014): 169-179.

[3] Hu, Hong Mei. "The Study on the Tourism Industry Competitiveness of Regional Based on Structural Equation Model." Applied Mechanics and Materials. Vol. 687. Trans Tech Publications, 2014. 
[4] MA, Yong, and Hui-ying CHEN. "A research on the evaluation index system of competitiveness of China city convention \& exhibition industry based of AHP [J]." Tourism Research 1 (2013): 002.

[5] Figini, Paolo, and Laura Vici. "Off-season tourists and the cultural offer of a mass-tourism destination: The case of Rimini." Tourism Management 33.4 (2012): 825-839. 